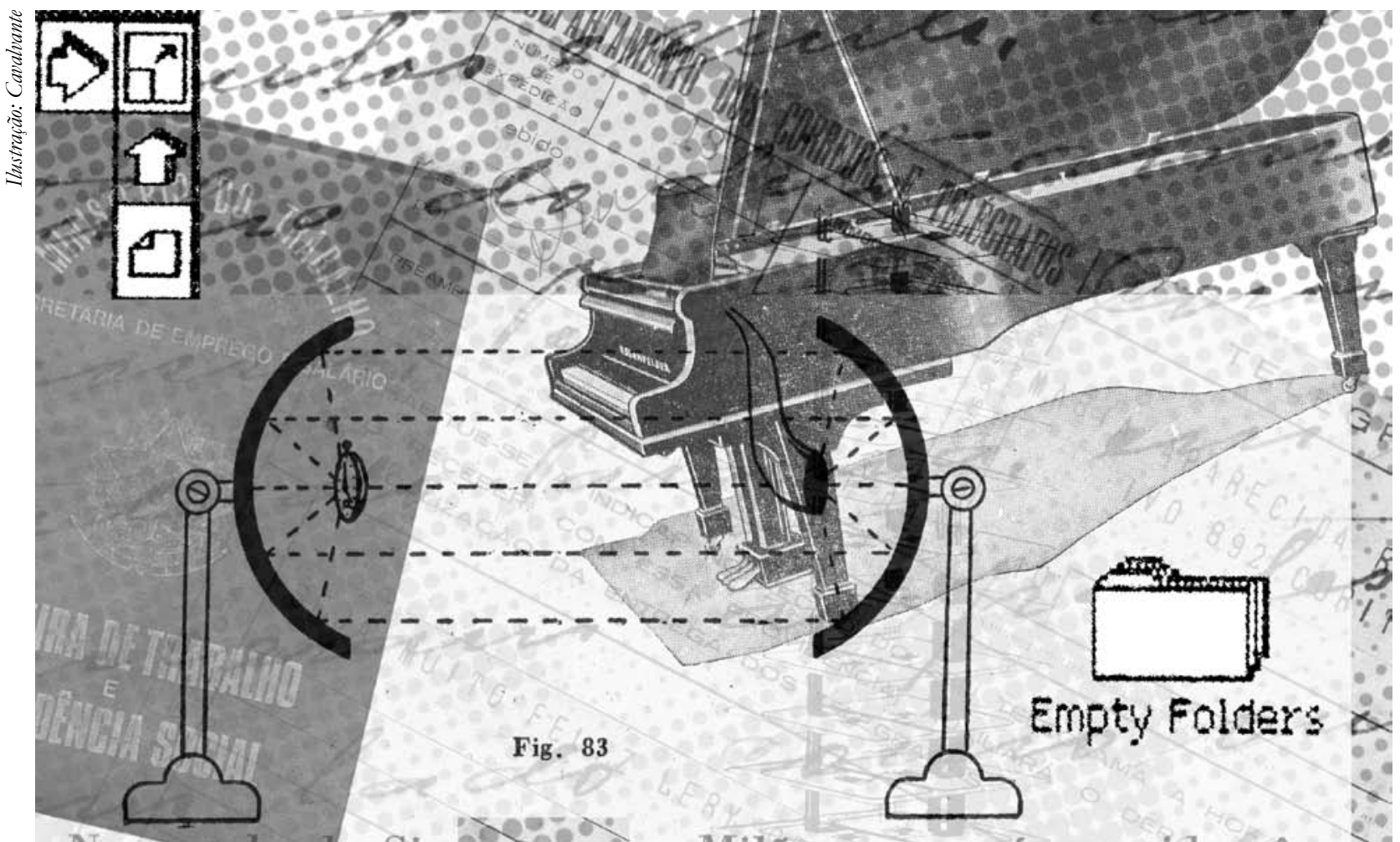

No castelo de Simgeneso ềm Milão, o som é repetido cêrca

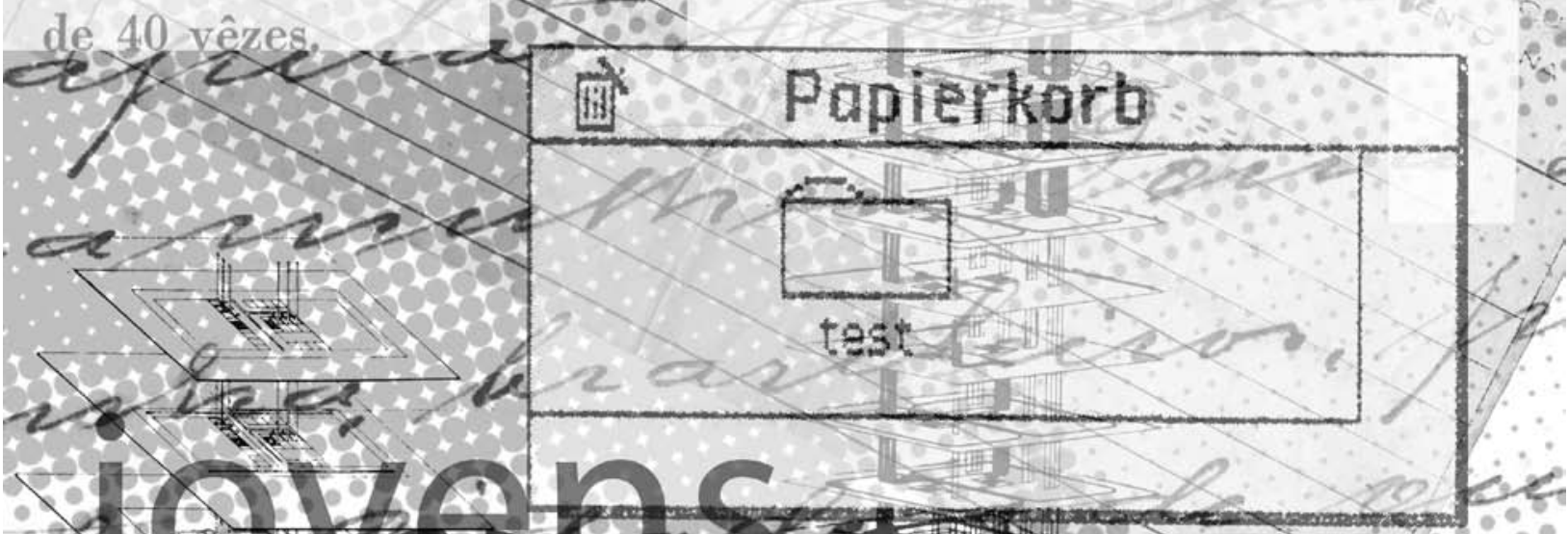

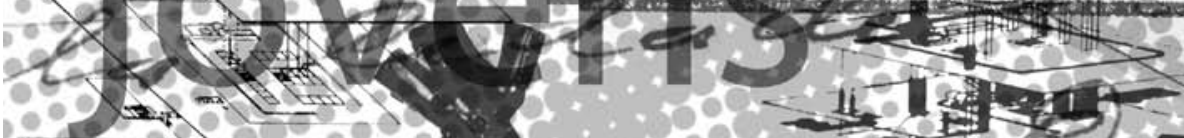

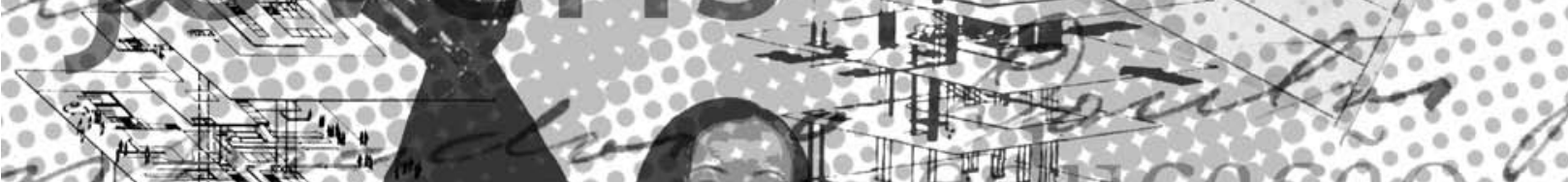

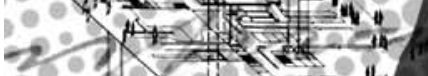
$\because$ म. Tonie 


\title{
Qualificação Profissional de Jovens e Adultos Trabalhadores: O Programa Nacional de Estímulo ao Primeiro EMPREgo EM Discussão
}

\author{
Carlos Soares Barbosa* \\ Neise Deluiz.*
}

\begin{abstract}
Resumo
Este artigo analisa as ações de qualificação profissional voltadas para os jovens das camadas populares, do Programa Nacional de Estímulo ao Primeiro Emprego (PNPE), no Rio de Janeiro. Resultados de pesquisa qualitativa indicaram que essas ações encaminham os jovens aos trabalhos precários, responsabilizando-os pela não inserção no mercado de trabalho formal. Ao não propiciar a formação de sujeitos políticos e sua participação na esfera pública, se limitam aos benefícios secundários, como sociabilidade e auto-estima, cumprindo o PNPE a função reservada às políticas focalizadas de alívio à pobreza, de contenção da questão social.
\end{abstract}

Palavras-chave: Educação Profissional; Políticas Públicas; Organizações Não-Governamentais; Juventude; Programa Nacional de Estímulo ao Primeiro Emprego (PNPE).

\section{INTRODUÇÃO}

No contexto atual de estreitamento e volatividade do mercado de trabalho, de extremas exigências de qualificações profissionais e do excedente de mão-de-obra pouco escolarizada e qualificada, um dos maiores desafios a serem enfrentados é a inserção dos jovens no mundo do trabalho, já que estes são os mais penalizados com o desemprego e com a precarização do trabalho, que se revela nos baixos rendimentos, altas jornadas de trabalho, instabilidade ocupacional, alta rotatividade e ausência de mecanismos de proteção social e trabalhista.

São os jovens na faixa etária de 15 a 24 anos das camadas populares os mais atingidos pelas mudanças no mundo do trabalho, pelas fragilidades do sistema educacional e os mais destituídos de apoio de redes de proteção, encontrando-se em maior estado de vulnerabilidade social. Entre os principais problemas com os quais os jovens brasileiros se deparam hoje estão: o acesso restrito à educação de qualidade, as frágeis condições para a permanência no sistema escolar, a dificuldade de se inserirem no mercado de trabalho formal, a luta pelo primeiro emprego

Historiador, graduado pela Universidade do Estado do Rio de Janeiro (UERJ) e mestre em Educação pela Universidade Estácio de Sá (Unesa). Prof. de História das redes municipal e estadual de ensino do Rio de Janeiro e integrante da equipe de formadores de educadores e coordenadores do Programa Nacional de Inclusão de Jovens (ProJovem) pela Fundação Darcy Ribeiro.E-mail: soares-carlos@ig.com.br.

** Socióloga, doutora em Educação pela UFRJ. Prof". do Mestrado em Educação da Universidade Estácio de Sá (Unesa). Prof́. adjunta (aposentada) da Universidade Federal do Rio de Janeiro (UFRJ).E-mail:ndelui_@uol.com.br.

Recebido para publicação em: 20/02/08. e a inadequada qualificação profissional. Tais dificuldades reforçam a necessidade urgente de políticas públicas voltadas para o aumento da escolaridade do jovem, a qualificação profissional, a participação social, a garantia do primeiro emprego - a fim de proporcionar-lhe experiência profissional -, além de uma política integrada de proteção social.

Entre as políticas públicas do atual Governo Federal em relação à qualificação profissional de jovens trabalhadores, privilegiamos como foco de estudo o Programa Nacional de Estímulo ao Primeiro Emprego (PNPE) ${ }^{1}$, que em uma de suas linhas de ação - o Consórcio Social da Juventude $(\mathrm{CSJ})^{2}-$, promove ações de qualificação profissional através de uma rede de organizações não-governamentais em parceria com o Ministério do Trabalho e Emprego (MTE).

Este artigo tem como objetivo identificar as finalidades das ações de qualificação profissional na concepção das ONGs participantes do Programa; a qualidade pedagógica dessas ações; e sua efetividade social e política, isto é, os impactos que ocasionaram no desenvolvimento da dimensão econômica (trabalho e renda), da dimensão comunitária (participação na comunidade) e da dimensão político-social (exercício da cidadania), na perspectiva de alunos e egressos dos cursos.

O artigo tem o propósito de apresentar os resultados de pesquisa desenvolvida com ONGs participantes do PNPE/CSJ no Rio de Janeiro³, em 2006-2007 e, para isso, a exposição buscará articular os três eixos fundamentais da investigação: educação de jovens e adultos / educação profissional; ONGs e a parceria público-privado; e a relação juventude e trabalho, no contexto das reformas políticas, econômicas e sociais engendradas no Brasil 
com a reestruturação do capital, que se intensificou a partir da última década do século passado.

\section{As políticas de Educação de Jovens e Adultos a partir dos anos 1990: focalização, descentralização e desre- gulamentação}

No Brasil, a educação básica de jovens e adultos tem sido marcada pela falta de compromisso político por parte do Poder Público, considerada uma educação paralela à educação elementar comum. As reformas constitucionais implementadas na década de 1990, por meio de Projetos de Leis e Decretos, assim como a LDB em vigor (Lei $\mathrm{n}^{\circ}$ 9394/96), complementaram o movimento de reforçar a educação de jovens e adultos (EJA) como uma educação de segunda classe (SAVIANI, 1997) ${ }^{4}$, se tomarmos como base a análise das políticas públicas em vigor nos últimos anos.

Alguns autores, como Ventura $(2001)^{5}$ e Romão (2002) ressaltaram a constituição de uma nova identidade da EJA ao longo dos anos de 1990, quando passou a ser caracterizada, segundo Di Pierro (2001) ${ }^{7}$, pelos cursos de qualificação profissional de curta duração, focados nos segmentos mais vitimados pelo atual modelo de acumulação do capital. Esta (re)configuração identitária da EJA e suas conseqüentes finalidades tornam-se mais compreensivas quando as analisamos frente ao conjunto de mudanças econômicas e políticas postas em prática no Brasil com a adoção das políticas neoliberais.

Essas políticas tiveram início no governo de Collor de Melo e foram intensificadas nos governos de Fernando Henrique Cardoso, como condicionalidade imposta para a renegociação da dívida externa e o retorno do país ao sistema financeiro internacional (FIORI, 1997) ${ }^{8}$. Cumprindo os postulados do Consenso de Washington, a Reforma do Estado Brasileiro foi pensada e articulada como meio de possibilitar lucros cada vez mais crescentes ao capital (MONTAÑO, 2007) ${ }^{9}$. Para os seus formuladores, a justificativa para a retirada da ação estatal dos setores sociais (saúde e educação), culturais, de proteção ambiental e de pesquisa científica e tecnológica era de que tais serviços ganhariam qualidade e eficiência, se saíssem do âmbito do Estado e ficassem sob a responsabilidade de organizações sociais públicas não-estatais (BARRETO, 1999) ${ }^{10}$, voltadas ao atendimento do interesse público. Defendiam, assim, uma nova relação entre Estado e sociedade civil por meio da parceria públicoprivado.

A área social sofreu profundamente os impactos das reformas, uma vez que a redução dos gastos públicos significou, na prática, a redução dos gastos sociais, gerando conseqüências graves para as camadas populares, como deterioração das suas condições de vida e do trabalho, desemprego, crescimento do mercado informal de trabalho, exploração do trabalho infanto-juvenil, entre outras. Diante da crescente pauperização de enormes parcelas da sociedade, o "Estado passon a desenvolver politicas sociais focalizadas, atuando apenas - por meio de medidas compensatórias - nas conseqüências sociais mais extremas do capitalismo contemporâneo" (OLIVEIRA; DUARTE, 2005) ${ }^{11}$.

Essas políticas visam o alívio à pobreza, ou seja, "a retirada da condição de miséria daqueles que sequer conseguiram alcanşar as condicôes minimas de sobrevivência" ${ }^{\text {, }}$, com o propósito de impedir que as péssimas condições de sobrevivência de uma parcela significativa da população causem convulsões sociais e protestos que venham gerar obstáculos à governabilidade, assim como à expansão e acumulação do capital. Não mais orientadas pela lógica do cidadão detentor de direitos, mas sim pela lógica do cidadão-consumidor, as políticas focais não visam à superação da condição de dependência dos indivíduos às políticas de caráter assistencialistas e nem a sua integração à sociedade salarial através do emprego formal, mas sim a sua inserção na sociedade do não-emprego ${ }^{13}$.

A educação não ficou ilesa a este contexto de reformas. As políticas educacionais passaram a exigir da educação produtividade, eficiência e qualidade, obtidas por meio da relação custobenefício. Para os experts das agências internacionais, os países pobres deveriam investir naquilo que auferisse maiores ganhos futuros. Para eles, o maior retorno não viria com o investimento na escolarização de jovens e adultos, ou no ensino médio, tecnológico e superior, mas sim na educação básica de crianças e adolescentes e na qualificação profissional inicial. Mas não em uma formação profissional cara e prolongada.

Muitas mudanças marcaram a educação de jovens ao longo da década de 1990, período em que essa modalidade foi se esvaziando como política de Estado. Tal esvaziamento faz parte de um projeto que desloca uma parcela do atendimento de jovens e adultos para o Ministério do Trabalho e Emprego (MTE), ampliando sua linha de atuação com a escolarização e a formação profissional do trabalhador. Isso foi uma das conseqüências das alterações efetuadas na formação profissional e na educação de jovens e adultos, a partir da promulgação da Lei de Diretrizes e Bases da Educação no 9394/96 e do Decreto no 2208/9714.

A dispersão das políticas e de ações entre os setores público e

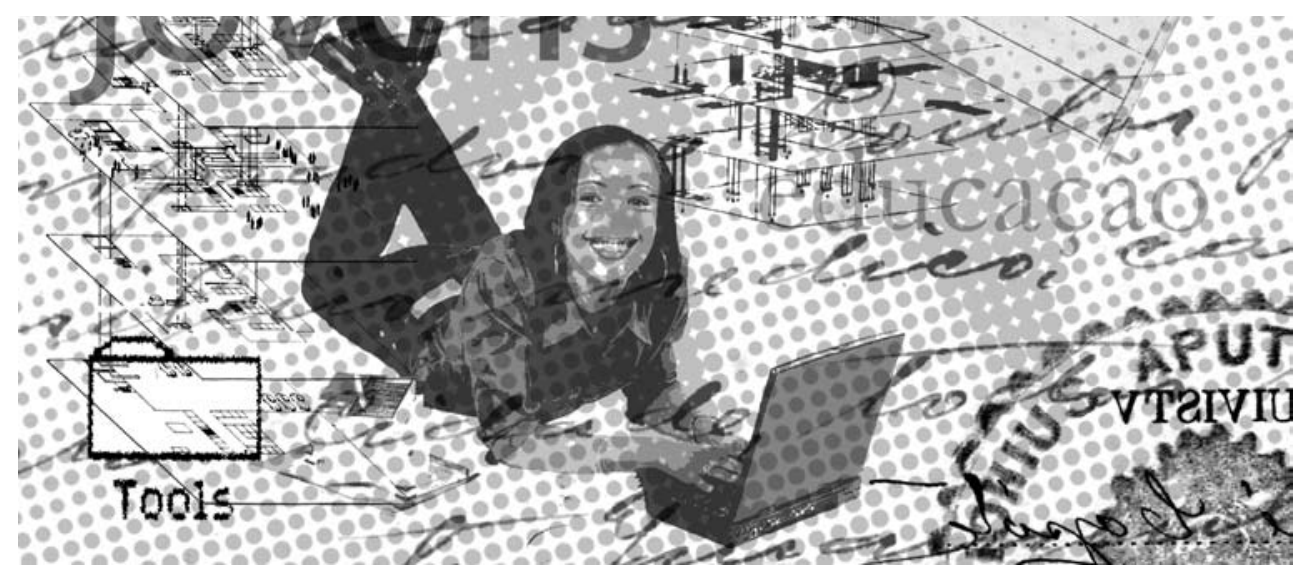




\section{$\bullet \bullet \bullet$}

\section{o conceito de público}

foi sofrendo alterações

profundas, principalmente

com a desresponsabilização

do Estado na execução

de politicas sociais e o

descompromisso com a

garantia dos direitos sociais.

privado foi uma das marcas das políticas de educação de jovens e adultos durante os dois governos de Fernando Henrique Cardoso. Através do Plano Nacional de Qualificação Profissional (Planfor), $\mathrm{o}$ atendimento às demandas por qualificação de uma população jovem e adulta de baixa escolaridade se deu por uma rede de qualificação profissional formada por cursos de nível básico, fragmentados e de curta duração, dissociados da educação básica e de uma política de formação continuada, tendo sua execução deixada a cargo de diversas instituições da sociedade civil como ONGs, sindicatos, entidades religiosas, entre outras.

Com a mudança do governo federal, o Planfor foi substituído, em 2003, pelo Plano Nacional de Qualificação (PNQ), que buscava a superação da condição de política compensatória (BRASIL/ MTE/SPPE/DEQ, 2003) ${ }^{15}$. Para isso, o governo, através do MTE, admite o problema do emprego como uma questão social e a qualificação profissional na perspectiva do direito social, devendo ser objeto de uma política nacionalmente articulada e controlada socialmente. Mais do que uma ação formativa de conteúdo técnico, visando tão somente uma inclusão produtiva, a qualificação deveria orientar-se para a busca de uma inclusão cidadã (OLIVEIRA, 2007) ${ }^{16}$.

Não obstante o caráter recente dos dados dos dois mandatos do governo em relação às políticas de educação profissional de jovens e adultos, o que tem se verificado até o momento é que as propostas contidas no $\mathrm{PNQ}$, na prática, caminharam em outra direção. A política de educação profissional tem se processado mediante programas focais e contingentes, resultando em mera oportunidade de certificação, sem assegurar nem inclusão, nem permanência. Uma outra característica dos programas do governo atual é a continuidade do sistema de parceria públicoprivado, embora negado no plano do discurso. O que se verifica é o crescente repasse de recursos públicos para o setor privado justificado pela impossibilidade do Estado em cumprir com suas funções (KUENZER, 2006) ${ }^{17}$.
Quanto à educação profissional de jovens e adultos, permanecem as lacunas constatadas no Planfor e criticadas pelos formuladores do PNQ, tais como a desarticulação das políticas públicas de qualificação com as de educação; repasse dos recursos públicos ao setor privado; o mau uso destes recursos diante das fragilidades e deficiências no sistema de planejamento, monitoramento e avaliação; ênfase nos cursos de curta duração, voltados ao tratamento fundamentalmente das habilidades específicas; segmentação e desarticulação das políticas públicas, desenvolvidas por diversos Ministérios (Educação, Trabalho e Renda, Ciência e Tecnologia, Desenvolvimento e Combate à Fome), que disputam, muitas vezes, o mesmo público, através de diversas ações ${ }^{18}$, que a nosso ver, em grande medida, se vinculam às políticas de alívio da pobreza.

\section{As ONGs e educação: a parceria privilegiada}

O crescimento das ONGs e sua parceria com o Estado são fenômenos globais, iniciados nos países centrais do capitalismo mundial na década de 1980. A adesão do Brasil ao sistema de parceria público-privado se explicita no Plano Diretor da Reforma do Aparelho do Estado e, em especial, por meio da Medida Provisória $\mathrm{n}^{\circ} 1.591 / 97^{19}$, que dispõe, entre outras coisas, sobre a criação do Programa Nacional de Publicização ${ }^{20}$ e a qualificação de entidades como organizações sociais. A partir dela, o conceito de público foi sofrendo alterações profundas, principalmente com a desresponsabilização do Estado na execução de políticas sociais e o descompromisso com a garantia dos direitos sociais. Baseando-se em resultados e reduzindo direitos em serviços, no qual o cidadão transforma-se em cliente-consumidor, a transferência de dinheiro público para as entidades do "Terceiro Setor" não só altera a relação cidadão-Estado, uma vez que as demandas passam a se dirigir à justiça social, e não mais aos órgãos da administração estatal, como também reduz o espaço público do cidadão ao reduzir o seu poder de negociação (GOHN, 2002) ${ }^{21}$.

O sistema de parceria também ocorreu nos programas de educação profissional de nível básico do Ministério do Trabalho (MTE), na vigência do Planfor e, posteriormente, do PNQ. Ainda que o envolvimento entre ONGs e educação não seja um episódio exclusivo da década de 1990, a participação dessas organizações no campo educacional se intensifica legalizada pela nova LDB. Desde então, as ONGs se voltaram para a qualificação de jovens e adultos de baixa renda e escolaridade, junto com outras organizações da sociedade civil, como sindicatos, instituições empresariais, escolas técnicas públicas e privadas, entre outras (DELUIZ; GONZALEZ; PINHEIRO, 2003) ${ }^{22}$. A atuação das ONGs nas ações de qualificação profissional se intensificam neste Governo com a implementação do Consórcio Social da Juventude (CSJ), uma das linhas de ação do Programa Nacional de Estímulo ao Primeiro Emprego (PNPE).

Como se pode observar, descentralização (da gestão e do financiamento), focalização (dos programas e populações beneficiárias), privatização dos serviços e desregulamentação se tornaram características das políticas vinculadas a EJA nas 


\section{O desemprego dos jovens é um dos mais graves problemas da atualidade, pois a dramática situação da falta de postos de trabalho e as dificuldades de acesso à rede de proteção social transformam a fase da juventude em uma etapa de incerteza.}

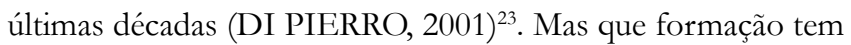
sido oferecida aos trabalhadores? A que interesse ela atende?

Trata-se de uma formação aligeirada, fragmentada e voltada às demandas do mercado. Contrários a essa concepção de educação, Marx (1978) ${ }^{24}$ e Gramsci (1995) ${ }^{25}$ concebiam uma formação omnilateral, isto é, que possibilitasse o desenvolvimento de todas as potencialidades humanas. Para isso, faz-se necessário o rompimento de uma educação instrumental, especializada e tecnicista, uma vez que não vislumbra o Homem na sua totalidade e sim o "aperfeiçoamento" da mercadoria - força de trabalho. Uma educação discriminatória, visto que reforça e perpetua as desigualdades, na medida em que, sendo unilateral, se preocupa apenas com um aspecto da formação.

Gramsci (1995) 26 denuncia que as escolas "preocupadas em satisfazer interesses práticos imediatos tomam a frente da escola formativa". Neste sentido, defende a educação politécnica, isto é, uma educação que se apóia na concepção de que as relações de trabalho são também relações pedagógicas, não se reduzindo a um mero instrumento útil de preparação para o trabalho, mas sim a um processo de busca com fins à superação da alienação do trabalho. Para tanto, a escola deve assegurar "a cada governado a aprendizagem gratuita das capacidades e da preparação técnica geral, necessária ao fim de governar ${ }^{\prime 27}$ e se orientar para a formação de intelectuais orgânicos da classe trabalhadora, com vistas à construção de projetos contra-hegemônicos.

\section{Juventude e trabalho: o desafio do primeiro emprego}

O desemprego dos jovens é um dos mais graves problemas da atualidade, pois a dramática situação da falta de postos de trabalho e as dificuldades de acesso à rede de proteção social transformam a fase da juventude em uma etapa de incerteza.
Ainda que o desemprego seja um problema geral desde os anos 1990, pesquisa realizada em 2005 pelo Dieese ${ }^{28}$ mostra que no Brasil, num universo com 3.241 milhões de trabalhadores sem emprego com mais de 16 anos, 1.473 milhão está na faixa etária entre 16 e 24 anos, o correspondente a 45,5\% do total. Também são bastante reveladores os números sobre o desemprego juvenil no primeiro mandato do Governo atual (2003-2006). De acordo com o Cadastro Geral de Empregados e Desempregados (Caged) $)^{29}$, apenas $15 \%$ das novas oportunidades que surgiram nesse período foram ocupadas por pessoas na faixa etária de até 24 anos. A Síntese dos Indicadores Sociais / IBGE ${ }^{30}$ de 2006 mostrou que, de 2004 para 2005, a taxa de desemprego subiu de $18,9 \%$ para $20,8 \%$ entre jovens de 10 a 17 anos, e de $16,9 \%$ para $17,8 \%$, ente jovens de 18 a 24 anos.

Entre as maiores dificuldades dos jovens está a conquista do primeiro emprego, uma vez que se encontram nas piores condições de competição em relação aos adultos que, com freqüência, acabam preenchendo as vagas antes mesmo de serem acessadas pelos jovens, já que possuem, na maioria das vezes, escolaridade mais elevada, alguma experiência profissional e qualificação. Assim, no primeiro mandato do Governo Lula, só uma em cada dez vagas com carteira assinada abertas no Brasil foi ocupada por alguém que procurava se colocar no mercado pela primeira vez (POCHMANN, 2007) ${ }^{31}$.

As dificuldades dos jovens de inserção no mercado de trabalho formal vêm se agravando ao longo da década de 1990 . Pochmann $(2000)^{32}$ salienta que durante essa década, no Brasil, as ocupações por conta própria foram as mais geradas para os jovens. Elas tiveram um aumento de $51 \%$, ao passo que o emprego assalariado para os jovens foi reduzido em $22,8 \%$. Embora a redução do emprego assalariado tenha ocorrido de maneira generalizada, ele encontra-se fortemente presente entre os jovens, tornando-se a ocupação autônoma a possibilidade cada vez mais viável de inserção dos jovens no mercado de trabalho. No final do século passado, a média entre dez ocupados com idade entre 15 e 24 anos era de quatro autônomos para seis assalariados, vivendo toda a precariedade do trabalho autônomo: baixos rendimentos, instabilidade ocupacional, altas jornadas de trabalho, alta rotatividade e ausência de mecanismos de proteção social e trabalhista.

Quanto à escolaridade da população juvenil, a Pesquisa Nacional por Amostra de Domicílios (PNAD, 2005 apud SALGADO, 2005) $)^{33}$, realizada em 2003, revelou que, dos 23,4 milhões de jovens de 18 a 24 anos, 15,4 milhões estavam fora da escola, sendo que $4,9 \%$ (em torno de 753,4 mil) eram analfabetos e 35,3\% (5,4 milhões) não haviam concluído o ensino fundamental. Precocemente afastados da escola, grande parte dos jovens de 18 a 24 anos também não estavam inseridos no mercado de trabalho formal e, dentre esses, 14 milhões (60\%) desenvolviam algum tipo de ocupação.

A passagem do jovem da escola para o mundo do trabalho é determinada pelas dificuldades da sobrevivência da família. Geralmente, quanto menor a renda familiar, maior a proporção de jovens que precisam trabalhar. Por outro lado, as mudanças realizadas no mundo do trabalho têm alterado as exigências para 
a entrada no mercado, tornando cada vez mais prementes as necessidades de jovens e adultos trabalhadores em aumentar sua escolaridade e qualificar-se profissionalmente, o que procuram fazer, dentre outras formas, por meio de projetos ou programas estatais desenvolvidos em parceria com organizações da sociedade civil, como é o caso do Programa Nacional de Estímulo ao Primeiro Emprego (PNPE).

\section{As ONGS NO CAMPO DA QUALIFICAÇÃO PROFISSIONAL: O PNPE/CSJ EM DISCUSSÃO}

As entidades executoras investigadas ${ }^{34}$, participantes do PNPE / Consórcio Social da Juventude no Rio de Janeiro, apresentam algumas diferenças quanto à prática e à forma de gestão. Embora haja uma referência comum a seguir, estipulada pelo MTE, não se pode falar das entidades de modo único, isto é, como se as entidades operassem no Consórcio de forma semelhante. Alguns fatores são relevantes para essa diferenciação:

(1) O perfil das entidades e dos educadores, sua missão e os posicionamentos políticos e ideológicos dos seus gestores.

(2) O critério de seleção dos jovens. Há entidades cuja demanda é quatro vezes maior do que o número de vagas oferecidas, o que a leva realizar uma seleção não baseada somente na condição de vulnerabilidade dos inscritos, mas sim em outros critérios, como prova escrita, dinâmica de grupo, entrevista coletiva e/ou prioridade aos que possuem ensino médio completo ou estejam cursando o terceiro ano. Por outro lado, há entidades em que a demanda é menor do que as vagas oferecidas e, para que o curso não deixe de ser realizado, matriculam todos os jovens que as procuram, independente se eles se enquadram ou não no perfil priorizado pelo Consórcio.

(3) O local onde o curso é realizado. Há cursos que são oferecidos dentro da comunidade onde mora a maioria dos jovens participantes do Programa. Nestes, o grau de relacionamento entre eles, de cumplicidade ou de animosidade, é bem maior do que nos cursos oferecidos na área central da cidade, que aceitam jovens oriundos de diferentes regiões da cidade.

(4) As oficinas oferecidas. Há cursos que exigem dos jovens uma comunicação maior e o trabalho em equipe, ao passo que outras requerem um comportamento mais individualizado.

Reconhecer as diferenças entre as entidades executoras investigadas não significa dizer que elas não apresentem pontos convergentes. São esses traços comuns em relação às finalidades e à qualidade pedagógica das ações de qualificação profissional na concepção das entidades executoras que ressaltaremos a princípio.

\section{Objetivos e finalidades das ações de qualificação pro- fissional na concepção das entidades executoras}

Reconhecendo o emprego juvenil como um dos principais desafios do Governo Lula, o Programa Nacional de Estímulo ao
Primeiro Emprego / Consórcio Social da Juventude tem como foco "o fomento à geração de postos de trabalho formais e preparação para oprimeiro emprego" (BRASIL. Ministério do Trabalho e Emprego. Termo de Referência, 2003) ${ }^{35}$. Para isso, as entidades conveniadas têm o dever de inserir, no mínimo, 30\% dos jovens nele matriculados, após a conclusão de no mínimo $80 \%$ da carga horária prevista para as ações de qualificação. Para o MTE, o primeiro emprego não se restringe ao emprego de carteira assinada e aos demais direitos trabalhistas garantidos. As diversas modalidades do mercado informal - trabalho autônomo, prestação de serviços, cooperativismo, empreendedorismo, serviço temporário e estágios -, são consideradas na referida percentagem.

A inserção no mercado formal é uma das principais dificuldades apontadas pelos coordenadores das entidades pesquisadas, principalmente dos jovens que possuem baixa escolaridade e não têm experiência profissional. Essas dificuldades são ressaltadas por Mesquita (2006) ${ }^{36}$ quando aponta que o PNPE estimulou 38 mil empregos desde 2003, enquanto o universo no país é de quatro milhões de jovens desempregados. Segundo o autor, os contemplados pelo Programa trabalham por um ano e ainda assim encontram dificuldades de inserção no mercado, pois não há uma política de continuidade.

Diante disso, e em consonância com os objetivos do Consórcio Social da Juventude ${ }^{37}$, a promoção de atividades autônomas e o despertar do espírito empreendedor são as finalidades principais da qualificação profissional para as entidades investigadas. Observando os cursos oferecidos - serigrafia, manicure, artesanato, marcenaria, construção civil, gastronomia, fotografia, dança, teatro, educadores sociais -, percebe-se que eles conduzem para esse fim.

Para justificar o empreendedorismo como o caminho viável de inserção dos jovens no mercado de trabalho, os agentes das entidades investigadas utilizam-se da idéia de que a qualificação

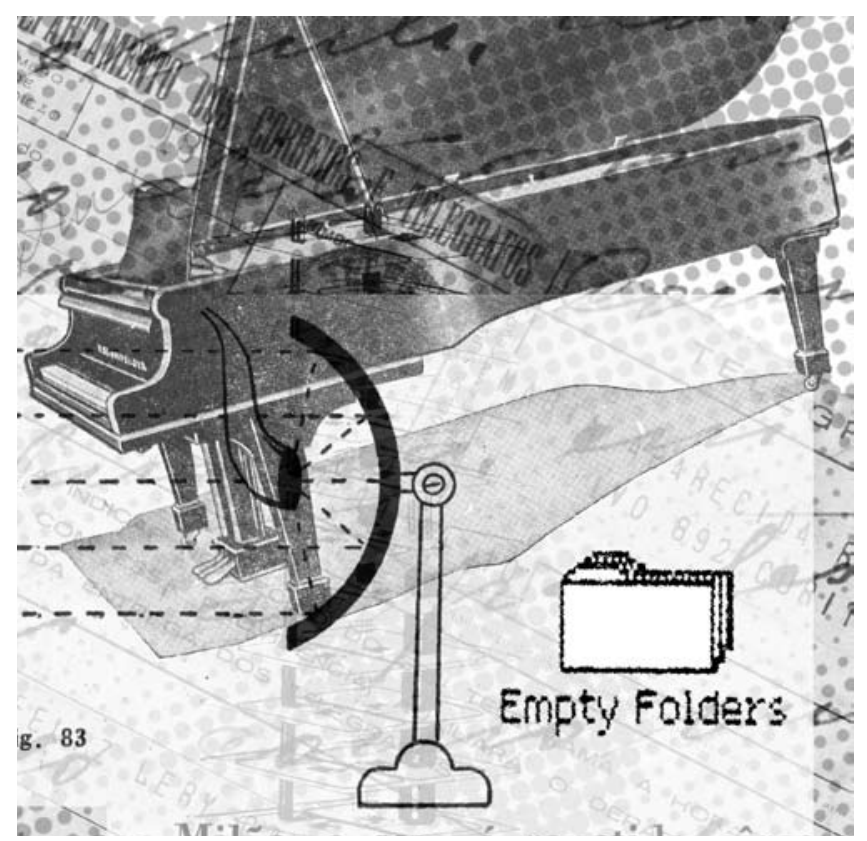


profissional garante aos trabalhadores melhores chances no mercado, embora, após as mudanças ocorridas com a reestruturação produtiva não haja mais como garantir a linearidade entre qualificação e inserção no mercado de trabalho, como já ressaltaram Frigotto $(1998)^{38}$, Del Pino $(2002)^{39}$ e Castel $(1998)^{40}$. Tal discurso alimenta a falsa crença de que o problema do desemprego reside na desqualificação dos trabalhadores, isto é, de que trabalho não falta, o que falta são trabalhadores qualificados, atribuindo-se, assim, a responsabilidade pela inserção profissional aos próprios indivíduos.

Sem questionar as causas estruturais do desemprego e as dificuldades de inserção no mercado de trabalho, e sem mencionar a falta de uma política pública efetiva de geração de empregos, trabalho e renda, parte-se do pressuposto que as dificuldades de inserção no mercado para os jovens são proporcionalmente minimizadas quanto mais eles se qualificam. A idéia fomentada é a de que eles estão se auto-investindo, posto que os indivíduos devem se capacitar para serem empregáveis. $\mathrm{Na}$ concepção das entidades investigadas, para garantir a empregabilidade os jovens devem investir no seu nível de capital humano que, segundo Davenport (apud PIRES, 2005) ${ }^{41}$, agora compreende "capacidade (entendida como conhecimento, habilidade e talento), comportamento (formas observáveis de agir que contribuem para a realização de uma tarefa) e empenho (aplicação consciente de recursos mentais e físicos para determinado fim)”. Desse ponto de vista, não há mais mercado de trabalho, mas sim "mercado de capital humano" ${ }^{\prime 2}$, onde cada trabalhador é um empreendedor: ganha mais se investe mais.

Ainda que as dificuldades da conquista do primeiro emprego e a precarização do trabalho se acentuem na medida em que as práticas neoliberais se tornam hegemônicas, as análises dos grupos focais realizados com os jovens vão ao encontro do resultado das pesquisas de Guimarães (2005) ${ }^{43}$ e Batista $(2007)^{44}$, que apontam o quanto o trabalho é uma categoria central para os jovens. É na esperança da obtenção do primeiro emprego - com carteira assinada e os demais direitos trabalhistas garantidos - que os jovens participam do Programa. Suas expectativas, no entanto, são frustradas desde o momento de sua entrada, quando os gestores das entidades afirmam não haver como garantir a esperada inserção.

Nesse sentido, diante da impossibilidade de satisfação de empregos e em meio à crise da sociedade salarial (CASTEL, $1998)^{45}$, as entidades investigadas buscam adequar os alunos ao contexto do não-emprego, fomentando o protagonismo juvenil e a busca de novas alternativas, como o empreendedorismo e o cooperativismo, como os caminhos viáveis de sua sobrevivência. Nas entrevistas realizadas com as coordenadoras, todas constataram a crescente seletividade do mercado e as mudanças operadas no mundo do trabalho sem, contudo, apontar suas causas estruturais. Naturalizam as mudanças ocorridas no mundo do trabalho e, como tal, não vislumbram quaisquer possibilidades de alteração do modelo socioeconômico constituído.

Isso significa que as entidades operam, em parte, pela lógica da racionalidade instrumental apontada por Singer (1996) ${ }^{46}$, à medida que baseiam suas ações na mudança de comportamentos e valores que levam os jovens a se tornarem empregáveis, adequando-se à competitividade e à seletividade do mercado. As entidades cumprem a função reservada à educação no sistema capitalista, como salienta Mészáros (2005) ${ }^{47}$, de internalizar nos indivíduos os valores do sistema a fim de criar um consenso, levando-os a defender como seus os interesses do capital.

Não tendo as entidades o compromisso de inserção para com todos os participantes do Programa e agindo mais na aparência do que na essência sobre a análise da crescente restrição dos postos de trabalho e as finalidades da qualificação profissional, a inserção de alguns interfere na subjetividade dos jovens não selecionados, levando-os muitas vezes a se auto-culpabilizarem por sua não inserção, pelo seu fracasso, já que, segundo a retórica neoliberal, no mercado todos têm a mesma chance de oportunidade, tratando-se tão somente de uma questão de mérito, competência e talento.

Apesar das coordenadoras afirmarem que as ações de qualificação profissional têm como objetivos, além do conhecimento técnico do ramo estudado, a construção da "consciência crítica" e a inclusão social, no PNPE/CSJ as ações visam instrumentalizá-los no caminho da empregabilidade, além de fomentar outras formas de inserção como meio de driblar as restrições do mercado formal. As ações educativas se realizam mais na perspectiva de adaptação dos jovens ao modelo econômico vigente e aos trabalhos precarizados que demandam pouca qualificação e baixa escolarização.

\section{Qualidade pedagógica das ações de qualificação profissional}

O estímulo à elevação da escolaridade é um dos objetivos do Consórcio Social da Juventude. Assim, para que o jovem possa participar do PNPE, além não ter tido vínculo empregatício anterior e de ser membro de família com renda mensal per capita de até meio salário mínimo, é preciso que esteja matriculado e 


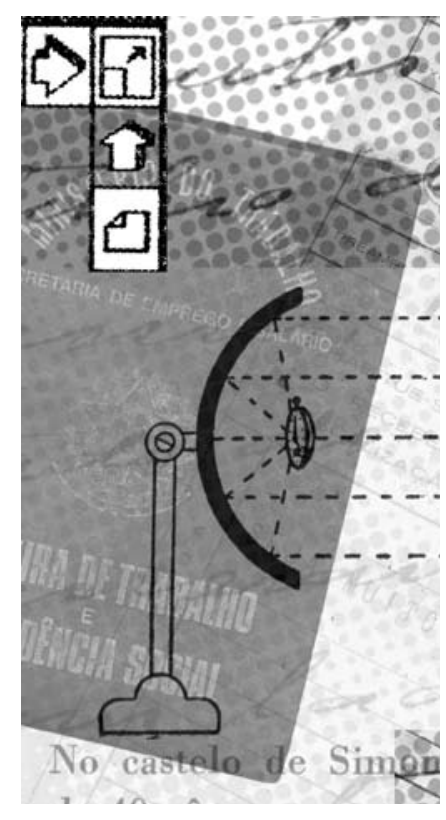

freqüentando regularmente estabelecimento de ensino fundamental ou médio, cursos de Educação de Jovens e Adultos, ou ainda que tenha concluído o ensino médio, entre outras exigências. Apesar disso, o Programa não prevê uma articulação com as Secretarias Municipal e Estadual de Educação, permanecendo a "divisão de tarefas" entre o MTE e o MEC em relação às políticas de Educação de Jovens e Adultos.

A permanência dessa divisão entre as políticas públicas dos referidos ministérios promove a continuidade da segmentação na educação profissional, apontada por Kuenzer (1999) ${ }^{48}$, em que é oferecida para a grande maioria - excluída do emprego ou submetida a trabalhos precarizados -, formação simplificada, de curta duração e baixos custos, ao passo que a oferta de educação científicotecnológica mais avançada fica restrita a um pequeno número de trabalhadores.

Analisando as políticas de educação profissional do Governo Lula, Leher (2005) ${ }^{49}$, Frigotto, Ciavatta e Ramos $(2005)^{50}$ evidenciaram que apesar da edição do Decreto $\mathrm{n}^{\circ} 5154 / 04^{51}$ a política de integração entre a educação básica e a educação profissional não é prioridade do novo Governo. Logo, o estímulo ao aumento da escolaridade é tão somente um princípio norteador na perspectiva do capital humano, onde o conhecimento torna-se a variável estratégica do mercado e da competição capitalista.

Com duração total de cinco meses ${ }^{52}$, as atividades educacionais no PNPE/CSJ são normalmente desenvolvidas dentro da lógica da fragmentação, sendo os primeiros meses reservados para a qualificação básica ${ }^{53}$, cuja carga é de 200 horas. Como os cursos se desenvolvem através de módulos, os jovens têm contato com diversos educadores contratados para trabalhar determinados conteúdos.

Em relação à parte específica, não existe um material próprio para as oficinas, e as aulas são predominantemente baseadas no fazer, na prática. Já em relação à qualificação básica, embora haja um material comum a todas as entidades executoras - os Cadernos Pedagógicos ${ }^{54}-$, o planejamento não é elaborado a partir desse material, mas sim de acordo com a concepção pedagógica de cada entidade, que se utiliza de outros recursos para facilitar a compreensão do conteúdo trabalhado.

As metodologias utilizadas pelas entidades executoras valorizam o conhecimento prévio dos jovens. Entendem que estes, embora possuam graus de escolarização diferentes, têm um conhecimento acumulado na sua experiência histórica. Metodologicamente, todas as entidades executoras pesquisadas afirmaram seguir a linha construtivista, em que, a partir do levantamento dos conteúdos trazidos pelos jovens, os professores os conduzam a descobrir o que realmente estão mais propostos a fazer.

A princípio, pode se ter a impressão de que o processo educativo concilia ciência e trabalho (dimensão técnico-científica), uma vez que a qualificação básica pauta-se no apoio à elevação da escolaridade e no trabalho através de temas transversais. Entretanto, por meio das observações de algumas aulas e pela coleta de dados com os diversos sujeitos da pesquisa, constata-se que a qualificação profissional no Consórcio não se conduz no viés da matriz crítica de Marx (1978) ${ }^{55}$ e Gramsci (apudMANACORDA, $1990)^{56}$, mas sim na perspectiva de Smith $(1985)^{57}$, ou seja, uma educação mínima necessária para que não se coloque em risco a ordem econômico-social.

Um curso de cinco meses tende mais ao disciplinamento do trabalhador à ordem econômica - o que seria possibilitado com a superação do empobrecimento cultural, posto que "um povo instruido e inteligente sempre é mais decente e ordeiro do que um povo ignorante e obtuso" (Smith, 1985) $)^{58}$-, do que à formação de intelectuais orgânicos das classes trabalhadoras, como propõe Gramsci $(1995)^{59}$.

Apesar disso, as coordenadoras afirmam que os cursos têm, também, a finalidade da construção do que chamam de "consciência crítica", que é desenvolvida mais enfaticamente durante a formação básica, nas "aulas de cidadania". As aulas de ética e cidadania são mais enfatizadas pelas entidades $(\mathrm{X}, \mathrm{Y})$ que têm como missão a formação política dos sujeitos e a formação de lideranças locais, ao passo que as aulas de Língua Portuguesa e Matemática são mais priorizadas por aquela entidade $(Z)$ em que a qualificação e a geração de renda são a missão principal. No entanto, apesar das discussões sobre o mercado de trabalho, sua seletividade e as dificuldades encontradas pelos jovens na obtenção do primeiro emprego ocorrerem no módulo de cidadania, elas se dão mais

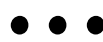

\section{As metodologias utilizadas pelas entidades executoras valorizam o conbecimento prévio dos jovens. Entendem que estes, embora possuam graus de escolarização diferentes, têm um conbecimento acumulado na} sua experiência bistórica. 
na perspectiva da constatação e adaptação a essas dificuldades do que na investigação das suas causas estruturais.

Nesse sentido, pela análise do material didático e pelos depoimentos coletados, a compreensão de cidadania não é da cidadania pautada no incentivo dos jovens à participação política na esfera pública, mas sim, como afirma Gohn (2002), da "cidadania outorgada, de cima para baixo, que promove a inclusão de individuos a uma rede de serviços de forma assistencial, em que os novos cidadãos se transformaram em clientes de politicas públicas administradas pelas entidades do Terceiro Setor" ${ }^{60}$.

Ainda que o Programa reserve a carga horária de 200 horas para a qualificação básica, ele não se operacionaliza de forma "desinteressada", como Gramsci $(1995)^{61}$ pensava a formação dos trabalhadores, isto é, despida do utilitarismo que visa apenas à formação rápida da mão-de-obra minimamente qualificada para o trabalho técnico. Portanto, mesmo que valorizem o conhecimento do aluno e integrem-no ao processo pedagógico, como se pretende na escola unitária, ainda que se tente conciliar o homo saber e o homo faber, ao garantir carga horária equivalente para a qualificação básica e específica, os cursos não se estruturam na perspectiva de uma educação integral e omnilateral.

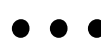

"a função das ONGs na parceria público-privado é servir de amortecedor das pressões populares", redirecionando as demandas dos trabalhadores não mais aos órgãos da administração estatal, cabe-nos indagar até que ponto elas estão comprometidas com a transformação social e suas ações educacionais voltadas

para a formação dos intelectuais orgânicos das classes trabalhadoras.
A qualificação desenvolvida no PNPE/CSJ, orientada para o desenvolvimento de competências flexíveis e empregáveis (DELUIZ, 2004 ${ }^{62}$; KUENZER, $1999^{63}$ ), e que capacita os jovens para ocupações com relações de trabalho precarizadas, não está voltada para desenvolver nesses trabalhadores um processo formativo integral na perspectiva da superação do trabalho alienado e nem preocupada com a formação "de um novo tipo de homem, um intelectual que seja especialista e ao mesmo tempo dirigente" (MANACORDA, 1990) ${ }^{64}$.

Pelo exposto, embora as entidades executoras orientem sua prática pedagógico-metodológica para a valorização da diversidade cultural, étnica, regional e de gênero e desenvolvam as temáticas do trabalho e da cidadania, conforme proposto no PNQ, não são abordadas questões críticas sobre o mundo do trabalho ou as relacionadas às desigualdades sociais geradoras da exclusão.

Como afirma Gohn $(2002)^{65}$, essas entidades atuam para incluir no sistema econômico atual, de forma precária e sem direitos sociais, os excluídos do modelo econômico. Cumprem a função reservada à educação na sociedade capitalista e denunciada por Mészáros $(2005)^{66}$, que é a de internalizar nos indivíduos os valores do capital, a fim de legitimar a posição que lhes foi atribuída na hierarquia social, induzindo-os, através de condutas certas e expectativas adequadas, a um conformismo generalizado. Desse modo, como esperar que os jovens sejam estimulados à crítica ao modelo socioeconômico e discutam perspectivas de mudanças se os gestores e coordenadores das entidades executoras assumem o discurso conformista de que não há mais possibilidade de mudanças?

\section{Efetividade social e política das ações de qualificação profissional}

O PNPE/CSJ, na sua essência, não se diferencia das políticas implementadas na década de 1990, sob viés neoliberal. Assim como as políticas focalizadas, o PNPE também centra sua atenção nos mais vulneráveis e, ao oferecer bolsa auxílio de $\mathrm{R} \$ 120,00$ aos jovens participantes, segue o formato das políticas sociais que, como nos mostraram Oliveira e Duarte $(2005)^{67}$, passaram orientar-se por meio da articulação, não mais entre trabalho e renda, mas sim entre renda e educação.

No grupo focal realizado com os egressos constatamos que a efetividade social e política das ações realizadas pelas entidades participantes do Consórcio restringem-se a benefícios secundários, como maior sociabilidade, responsabilidade e auto-estima, já que o curso não rendeu nenhuma oportunidade de emprego, trabalho e renda para a maioria dos jovens participantes.

Desmistificada a idéia de que o Programa garante a inserção dos jovens no seu primeiro emprego no mercado formal, a qualificação passa a ter um caráter mais voltado para a mudança de comportamentos sociais, em face da situação de risco e vulnerabilidade em que se encontra a maioria desses jovens. Neste sentido, os temas transversais: ética, cidadania, valores humanos, meio ambiente, sexualidade, violência, igualdade racial e eqüidade de gênero, são trabalhados na perspectiva da mudança de ati- 
tudes e comportamentos, como o respeito à diversidade (étnica, cultural, regional, sexualidade e gênero), o convívio com as diferenças, o respeito ao próximo, entre outros temas. É uma mudança de comportamento que pode ter, sem dúvida, reflexo na minimização das vulnerabilidades desses jovens em relação à violência.

Concordando com a premissa posta por Montaño $(2007)^{68}$ de que "a função das ONGs na

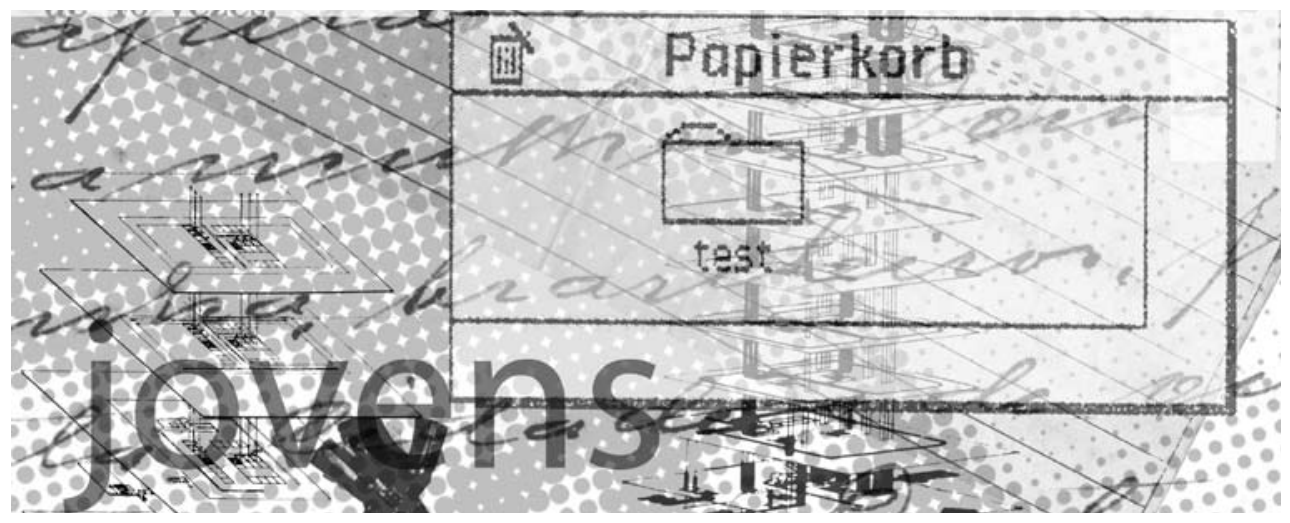
parceria público-privado é servir de amortecedor das pressões populares", redirecionando as demandas dos trabalhadores não mais aos órgãos da administração estatal, cabe-nos indagar até que ponto elas estão comprometidas com a transformação social e suas ações educacionais voltadas para a formação dos intelectuais orgânicos das classes trabalhadoras. Sobrevivendo cada vez mais com os recursos advindos do Estado, estariam as ONGs engajadas na elaboração de um projeto contra-hegemônico de sociedade $^{69}$ em que se opera a hegemonia do trabalho sobre o capital, como propõe Mészaros (2002) ${ }^{70}$, ou simplesmente a serviço do atual processo de reestruturação do capital e de toda lógica neoliberal?

Wood $(2003)^{71}$ e Montaño $(2007)^{72}$ evidenciaram a alteração efetuada no conceito gramsciano de sociedade civil com a implementação da parceria público-privado. Segundo aqueles autores, as dimensões de "luta" e "confronto" pela hegemonia de diferentes projetos societários foi cedendo lugar à idéia de interação, entendimento, consenso, colaboração e parceria. Mas "pensar numa sociedade civil desarticulada, apática, desmobilizada, é deixar este espaço para o controle hegemônico dos setores sociais que exercem a direção hegemônica na sociedade", afirma Montaño (2007) ${ }^{73}$. Nesse sentido, ao considerar as organizações da sociedade civil como articuladoras dos mesmos interesses - o de promover o bem geral da população -, subtrai-se a visão de sociedade civil como espaço contraditório e tenso, entranhada de diversos mecanismos de coerção (WOOD, 2003) ${ }^{74}$.

Contudo, é identificar os espaços de luta a fim de vislumbrar as potencialidades existentes. Desse modo, ao tempo em que as entidades cumprem suas ações no formato do Programa, em consonância com os postulados neoliberais, elas também podem suscitar o início de um novo ciclo de vida para alguns jovens, não só - como constatamos no grupo focal dos alunos atuais e egressos - por estimular a continuidade da vida escolar, podendo lhes possibilitar a conquista de outros espaços além dos "reservados" às camadas populares, mas também por possibilitar, além do encontro com outros jovens, um novo olhar sobre a sua realidade, novos conhecimentos e discussões políticas.

Gramsci nos ajuda a pensar a escola não como lócus da reprodução sem resistência, mas sim como espaço de disputa de diferentes concepções da realidade e de projetos individuais e societários em busca da hegemonia, o que nos leva a não

identificar os jovens cursistas como passivos receptores da ideologia dominante, e os coordenadores e educadores como meros transmissores dessa ideologia. Se analisamos as ONGs conforme Gramsci $(2005)^{75}$ pensou a escola e se as compreendemos não de modo único, uma vez que elas têm objetivos/missões diferentes e trabalham com jovens, coordenadores e educadores com perfis diferentes $^{76}$, podemos vislumbrar algumas possibilidades.

Não obstante o PNPE esteja estruturado com cursos fragmentados e de curta duração, conduzidos pela perspectiva da empregabilidade, de fomento nos jovens do espírito empreendedor, de adequação à sociedade do não-emprego e da autoresponsabilização pela não inserção no mercado de trabalho, as entidades executoras cumprem uma outra função reservada à escola: a socialização.

Participar dos cursos oferecidos pelo Consórcio Social da Juventude é algo relevante para os jovens, como constatamos nos grupos focais realizados. Os jovens brasileiros apresentam aspectos diferenciados, de acordo com suas condições econômica e social, de gênero, etnia, religião e local de moradia (centro e periferia, campo e cidade), que não podem ser desconsideradas. Todas essas especificidades, de certo modo, criam condições peculiares a cada jovem em relação à escolarização, à exposição de riscos e luta pela entrada no mercado de trabalho. Nessa perspectiva, ainda que cinco meses seja um período insuficiente para uma boa qualificação, as ações das entidades executoras podem causar outros impactos aos jovens, como contribuir para a minimização de suas vulnerabilidades sociais, através da conscientização dessa sua condição e ao estímulo à continuidade da escolarização.

Constituída por ONGs com perfis diferentes, o PNPE apresenta, em meio a uma formatação comum, diferentes configurações, pois os educadores não só trabalham seus conteúdos de modo único, como os jovens não se apropriam da informação e constroem o conhecimento de forma igual, já que vivenciam experiências cotidianas diferentes. No entanto, apesar das possibilidades apontadas, em geral, as ações das entidades executoras participantes do PNPE/CSJ cumprem o papel reservado à educação básica, formação técnico-profissional e dos processos de qualificação e requalificação orientados pelo Banco Mundial, que é de "mormente, produzir cidadãos que não lutem por seus direitos e pela desalienação do/ no trabalho, mas cidadãos 'participativos', não mais trabalhadores, mas colaboradores" (FRIGOTTO, 1998 ${ }^{77}$ ). 
Desse modo, apesar do discurso das entidades investigadas de que trabalham na perspectiva da construção do sujeito crítico e se preocupam com a formação política dos jovens, a pesquisa constatou que as ações de educação profissional não propiciam a formação política dos sujeitos individuais e coletivos no sentido da sua participação na esfera pública. Com o grupo focal de egressos, constamos que, finalizado o curso, eles não se envolvem em nenhum tipo de atividade realizada na comunidade, sejam elas de ordem política, cultural, esportiva, educativa ou recreativa, não se percebendo como sujeitos históricos ativos, agentes de mudança, nem mesmo local.

Pelo exposto, em grande parte, os resultados da presente pesquisa vão ao encontro das conclusões de Deluiz $(2006)^{78}$, quando investigou a atuação das ONGs que desenvolveram ações de qualificação profissional no âmbito do Planfor, no período de 2001-2003, no Estado do Rio de Janeiro, ou seja, de que as modalidades de educação de jovens oferecidas configuram-se como um paliativo ao desemprego, destinando-se a minimizar a pressão social pela obtenção de emprego e/ou participação. Muda-se o governo, mas permanece o formato das políticas focais, em nome da governabilidade.

\section{Considerações finais}

Chegamos às considerações finais deste artigo ressaltando as diferenças das ações em meio à unidade, visto que o institucional, as diferentes juventudes e o corpo docente fazem com que, na prática, haja diferentes configurações do PNPE/CSJ. Compreendendo que o conhecimento é sempre aproximativo e provisório, o presente trabalho não tem a pretensão de esgotar as ações do Consórcio Social da Juventude do Rio de Janeiro, formado por 17 ONGs que executaram ações no Estado do Rio de Janeiro, em 2006 e 2007, mas constituir-se em mais um instrumento de análise das políticas públicas implementadas na área de trabalho e educação durante o Governo Lula.

Apesar de o PNPE não apresentar diferenças marcantes da política de qualificação profissional do governo anterior, é preciso estar atento às contradições a fim de vislumbrar os espaços de luta e as possibilidades existentes. Estas não suplantam, porém, a compreensão de que os cursos aligeirados e de curta duração oferecidos pelo PNPE reforçam o apartheid social, reproduzindo e aprofundando as desigualdades sociais existentes, uma vez que, de forma unilateral, destinam aos jovens das camadas populares uma qualificação voltada para o segmento do trabalho repetitivo, de execução e operacionalização, ao passo que o trabalho criativo, de concepção e elaboração fica reservado para um outro grupo social.

Transmitido pelas entidades executoras não como um dever do Estado e um direito dos jovens, mas como uma oportunidade dada a eles pelo governo, o PNPE é concebido como benesse pelos jovens, que agradecem pela oportunidade dada, parecendo ter aprendido a lição da paciência, da conformação e da adaptação - comportamento esperado de todo bom parceiro e colaborador.
Diante de uma conjuntura potencialmente conflituosa, devido à enorme desigualdade social e ao crescimento da violência urbana, torna-se necessário enfrentar o esgarçamento e a fragmentação do tecido social. Apostando no "capital social" "79, as políticas acabam por buscar (re)estabelecer os laços danificados pela lógica neoliberal, tal como a família e o sentimento de pertencimento à comunidade e à sociedade. Talvez este seja o propósito das 100 horas reservadas ao Serviço Social Voluntário que os jovens devem cumprir ao longo dos cinco meses, mesmo que não haja uma orientação de como ele deva acontecer. Nesse sentido, mais do que a construção de uma "consciência crítica" ocorrida na práxis, o Serviço Social Voluntário deve promover nos jovens o fortalecimento de sua responsabilidade social, o que, em outras palavras, significa colaborar com a ordem econômica, política e social instituída. Não é por acaso que, no grupo focal realizado com os egressos, os jovens apontaram maior responsabilidade e sociabilidade como um dos principais benefícios ocorridos com eles, proporcionada pelos cursos realizados.

Pelo exposto, observamos que, se anteriormente os movimentos sociais necessitavam da participação popular para o seu fortalecimento, atualmente, para as ONGs, em face da sua parceria com o Estado, essa participação já não é mais vital, ocasionando, assim, uma mudança na compreensão acerca da cidadania. Esta deixa de ser compreendida como participação política dos sujeitos na esfera pública, passando a ser concebida por meio da colaboração, da co-responsabilidade e da "solidariedade social". Portanto, sabedor de que um curso de curta duração, aligeirado e fragmentado não proporciona uma qualificação profissional e

as modalidades de educação de jovens oferecidas configuram-se como um paliativo ao desemprego, destinando-se a minimizar a pressão social pela obtenção de emprego e/ou participação. Muda-se o governo, mas permanece 0 formato das politicas focais, em nome da governabilidade. 


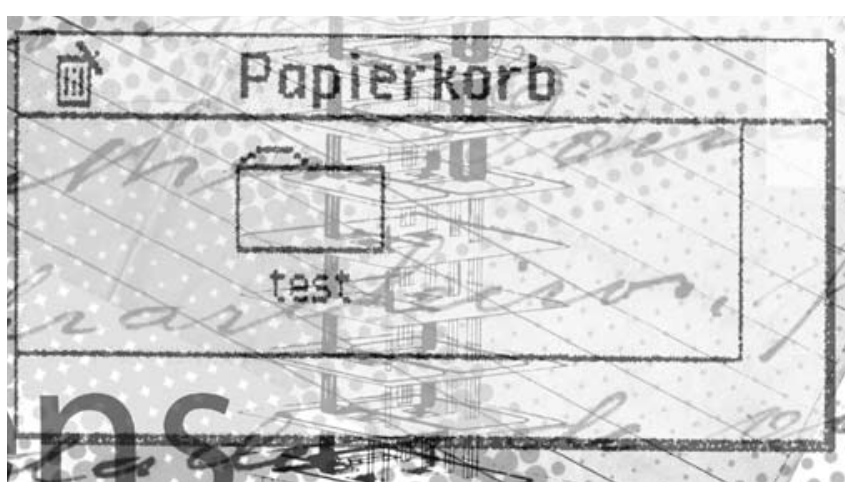

social de forma decente, estaria o Governo Lula, com o PNPE, investindo no capital social, como forma de enfrentamento da questão social, como é o propósito de toda política de alívio à pobreza?

\section{Notas:}

1 O PNPE vincula-se ao Plano Nacional de Qualificação (PNQ) e é uma ação do Governo Lula com vistas ao estímulo ao primeiro emprego de jovens trabalhadores da faixa etária de 16 a 24 anos que estão fora do mercado de trabalho, preferencialmente para aqueles que não tiveram ainda uma experiência de emprego formal. Criado pela Lei $\mathrm{n}^{\circ} 10.748 / 2003$, regulamentado pelo Decreto 5.199/2004, e estabelecido em regime de parceria público-privado, o PNPE recebe recursos do Fundo de Amparo ao Trabalhador (FAT); de diversos órgãos governamentais, como os Ministérios da Cultura, da Educação, do Desenvolvimento Agrário; e da iniciativa privada, como o "Sistema S", direcionados para a qualificação social e profissional do jovem no seu primeiro emprego.

2 A operacionalização das ações do CSJ se dá por meio de convênio entre o MTE e uma entidade da sociedade civil organizada, denominada entidade âncora, que, por sua vez, contrata uma rede de entidades para a execução das ações de qualificação básica, social e profissional e de inserção de no mínimo $30 \%$ dos jovens no mundo do trabalho. BRASIL. Ministério do Trabalho e Emprego. Plano Nacional de Qualificação (PNQ).Brasília: MTE/SPPE/ DEQ, 2003.

3 Trata-se da pesquisa Sociedade civil e as políticas de Educação de Jovens e Adultos: a atuação das ONGsno Rio de Janeiro (2006-2008), coordenada pela Prof. Dra. Neise Deluiz e financiada pelo $\mathrm{CNPq}$, na qual se insere a dissertação de mestrado Juventude, trabalho e educação: o Programa Nacional de Estímulo ao Primeiro Emprego em discussão, defendida por Carlos Soares Barbosa, no mestrado em Educação e Cultura Contemporânea da Universidade Estácio de Sá, em 2007.

4 SAVIANI, Dermeval. A Nova LDB: limites e perspectivas. In: ___ A nova lei da educação: trajetórias, limites e perspectiva, 3. ed, Campinas : Autores Associados, 1997. (Educação Contemporânea). p. 189-238.

5 VENTURA, Jaqueline. O Planfor e a educação de jovens e adultos trabalhadores: a subalternidade reiterada. Dissertação (Mestrado em Educação). Universidade Federal Fluminense, 2001.

6 ROMÃO, José E. Educação de jovens e adultos: problemas e perspectivas. In: GADOTTI, Moacir; ROMÃO, José. E. (Orgs.). Educação de jovens e adultos. 5.ed., São Paulo : Cortez, 2002.

DI PIERRO, Maria Clara. Descentralização, focalização e parceria: uma análise das tendências nas políticas públicas de educação de jovens e adultos. Educação e pesquisa, São Paulo, v. 27, n. 2, jul/dez. 2001, p. 321-337.

8 FIORI, José Luiz. Os moedeiros falsos. Petrópolis : Vozes, 1997.
9 MONTAÑO, Carlos. Terceiro setor e a questão social: crítica ao padrão emergente de intervenção social. 4. ed. São Paulo : Cortez, 2007.

${ }^{10}$ BARRETO, Maria I. As organizações sociais na reforma do Estado brasileiro. In: PEREIRA, Luiz C. Bresser; GRAU, N. C. (Orgs.). O público não-estatal na reforma do Estado. Rio de Janeiro : FGV, 1999.

${ }^{11}$ OLIVEIRA, Dalila A; DUARTE, A. política educacional como política social: uma nova regulação da pobreza. Perspectiva, Florianópolis, v. 23, n. 2, p. 255-278, jul./dez. 2005. p. 286.

${ }^{12}$ Id. Ibid., p. 285.

13 As políticas de integração são desenvolvidas através de diretrizes gerais num quadro nacional. É o caso das tentativas para promover o acesso de todos aos serviços públicos e à instrução, proporcionando ao indivíduo encontrar um lugar pleno na sociedade, inscrevendo-se na condição salarial com suas sujeições e garantias (CASTEL, Robert. As metamorfoses da questão social: uma crônica do salário. Petrópolis, (RJ): Vozes, 1998). As políticas de inserção obedecem a uma lógica de discriminação positiva: definem com precisão a clientela e desenvolvem estratégias específicas para elas. Como afirma Castel (1998) op. cit, p. 5559), "o sentido das politicas de inserção é ocupar-se dos válidos invalidados pela conjuntura".

${ }^{14}$ BRASIL. Leis, Decretos. Lei n. 9.394, de 20 de dezembro de 1996. Diário Oficial da União, Brasília, v. 134, n. 248, p. 27833-27841, 23 dez. 1996. Seção I. Estabelece as diretrizes e bases da educação nacional. Texto integral da lei de diretrizes e bases da educação nacional; Id. Decreto n. ${ }^{\circ} 2.208$, de 17 de abril de 1997. Diário Oficial da União, Brasília, v. 135, n. ${ }^{\circ} 74$, p. 7760-7761, 18 abr. 1997. Regulamenta o parágrafo 2 do art. 36 e os art. 30 a 42 da Lei n. ${ }^{\circ}$ 9.394, de 20 de dezembro de 1996, que estabelece as diretrizes e bases da educação nacional.

${ }^{15}$ BRASIL. Ministério do Trabalho e Emprego. Plano Nacional de Qualificação (PNQ).Brasília: MTE/SPPE/DEQ, 2003.

${ }^{16}$ OLIVEIRA, Roberto Véras de. A qualificação profissional como política pública. In: SAUL, Ana Maria; FREITAS, C. (Orgs). Políticas públicas de qualificação: desafios atuais. São Paulo: A + Comunicação/Unitrabalho, 2007.

${ }^{17}$ KUENZER, Acácia. A educação profissional nos anos 2000: a dimensão subordinada das políticas de inclusão. Educação \& Sociedade, Campinas, v. 27 , n. 96 , p. $877-910$, out, 2006. Número Especial.

${ }^{18}$ Como o Programa de Estímulo ao Primeiro Emprego;o Programa Fábrica de Escola; o Programa de Integração da Educação Profissional Técnica de Nível Médio ao Ensino Médio na Modalidade de Educação de Jovens e Adultos Proeja; o Programa Nacional de Inclusão de Jovens: Educação, Qualificação e Ação Comunitária - Projovem; o Brasil Alfabetizado, entre outros.

19 BRASIL. Leis, Decretos. Medida Provisória n. 1.591, de 09, outubro de 1997. Diário Oficial da União, Brasília, 10, out., 1997. p. 022835 Seção 2. Dispõe sobre a qualificação de entidades como organizações sociais, a criação do Programa Nacional de Publicização, a extinção do Laboratorio Nacional de Luz Sincrotron e da Fundação Roquette Pinto e a absorção de suas atividades por organizações sociais, e da outras providencias.

${ }^{20}$ Segundo Barreto (1999) op. cit., p. 112), "entende-se por processo de publicização a transferência dos serviços não-exclusivos do Estado para o setor público não-estatal ou terceiro setor mediante transformação de entidades estatais em organizações públicas nãoestatais, denominadas organizações sociais".

${ }^{21}$ GOHN, Maria da Glória. Educação, trabalho e lutas sociais. In: GENTILI, Pablo; FRIGOTTO, Gaudêncio. (Orgs.) A cidadania negada: políticas de exclusão na educação e no trabalho. $3^{\mathrm{a}}$ ed. Rio de Janeiro : Cortez , 2002.

${ }^{22}$ DELUIZ, Neise; GONZALEZ, Wania; PINHEIRO, Beatriz. ONGs e políticas públicas de educação profissional: propostas para a educação dos trabalhadores. Boletim Técnico do Senac, Rio de Janeiro, v. 29, n. 2, maio/ ago., 2003. 
${ }^{23}$ DI PIERRO, Maria Clara. (2001), op.cit.

${ }^{24}$ MARX, Karl. Manuscritos econômico-filosóficos e outros textos escolhidos. 2. ed. São Paulo : Abril Cultural, 1978. Os Pensadores

25 GRAMSCI, Antonio. Os intelectuais orgânicos e a organização da cultura. 9 ed., Rio de Janeiro : Civilização Brasileira, 1995.

${ }^{26}$ Id. ibid., p. 136.

27 Id. ibid., p. 137.

${ }^{28}$ Dados publicados no Jornal O Globo, Caderno Economia, Rio de Janeiro, 14 de setembro de 2006.

29 Dados publicados no Jornal O Globo, Caderno de Economia, Rio de Janeiro, 21 de dezembro de 2006

${ }^{30}$ Dados publicados no Jornal O Globo, Caderno de Economia, Rio de Janeiro, 30 de outubro de 2006

31 POCHMANN, Marcio. Síntese da análise feita pelo referido economista sobre os números do MTE para o primeiro governo Lula da Silva, publicado no Jornal O Globo, Caderno de Economia, segunda-feira, 26 de fevereiro de 2007. p. 13

${ }^{32}$ Id. A batalha pelo primeiro emprego: as perspectivas e a situação atual do jovem no mercado de trabalho brasileiro. São Paulo : Publisher Brasil, 2000

33 SALGADO, M.U.C. (Org.). Programa Nacional de Inclusão de Jovens (Projovem): manual do educador. Brasília, Presidência da República/ Secretaria Geral, 2005. Os dados não abrangem a área rural da Região Norte, exceto Tocantins.

34 Das 17 entidades que participaram do PNPE/CSJ no Rio de Janeiro, nos ano de 2006 e 2007, oferecendo oficinas de qualificação profissional a jovens de 16 a 24 anos em estado de vulnerabilidade social, selecionamos três delas como objeto deste artigo, aqui denominadas de X, Y e Z. Os sujeitos da presente pesquisa foram as coordenadoras (pedagógica e administrativa) das referidas ONGs, os alunos que estavam cursando à época e egressos. A coleta de dados nestas ONGs se deu em duas etapas, em 2006 e 2007, e as técnicas utilizadas foram cinco entrevistas semi-estruturadas, realizadas com as coordenadoras, e três grupos focais realizados com jovens, sendo um de egressos, com o intuito de compreender os significados produzidos sobre os cursos ministrados. Cada grupo focal contou com a participação de nove jovens.

35 BRASIL. Ministério do Trabalho e Emprego. Termo de Referência, 2003. Disponível em: < www.consorciodajuventuderj.org.br/documentos.asp.> Acesso em: 01, ago., 2006.

36 MESQUITA, Marcos Roberto. O desemprego dos jovens e as políticas públicas no Brasil pós 1990. Dissertação (Mestrado em Ciências Sociais), Instituto de Filosofia e Ciências Humanas, Unicamp: Campinas, 2006.

37 Tais objetivos são: (I) inserir jovens no mundo do trabalho por meio da intermediação de mão-de-obra e promoção de atividades autônomas; (II) preparar os jovens para o mercado de trabalho e ocupações que possam despertar o espírito empreendedor dos jovens; (III) proporcionar qualificação e atividades que possam despertar o espírito empreendedor dos jovens BRASIL. Ministério do Trabalho e Emprego. (2003) op. cit.

38 FRIGOTTO, Gaudêncio. Educação, crise do trabalho assalariado e do desenvolvimento: teorias em conflito. In: FRIGOTTO, Gaudêncio. (Org.). Educação e crise do trabalho. Petrópolis : Vozes, 1998. p. 25-54.

39 DEL PINO, Mauro. Política educacional, emprego e exclusão social. In: GENTILI, Pablo; FRIGOTTO, Gaudêncio (Orgs). A cidadania negada: políticas de exclusão na educação e no trabalho. $3^{\mathrm{a}}$ ed. Rio de Janeiro : Cortez, 2002.

${ }^{40}$ CASTEL, Robert. (1998) op. cit.
${ }^{41}$ PIRES, V. Economia da educação: para além do capital humano. São Paulo : Cortez, 2005. p. 82.

${ }^{42}$ Id. ibid., p. 77.

${ }^{43}$ GUIMARÃES, N.A. Trabalho: uma categoria-chave no imaginário juvenil? In: ABRAMO, H. W; BRANCO, P. P. M. Retratos da juventude brasileira: análises de uma pesquisa nacional. São Paulo : Fundação Perseu Abramo, 2005.

${ }^{44}$ BATISTA, Fátima da Silva. Jovens atores sociais em interlocução com o mundo do trabalho: possíveis mediações são feitas pela escola de Ensino Médio?. : Rio de Janeiro, 2007. Dissertação (Mestrado em Educação), Universidade Estácio de Sá, 2007.

${ }^{45}$ CASTEL, Robert. (1998), op. cit.

46 SINGER, Paul. Poder, política e educação. Revista Brasileira de Educação, Rio de Janeiro, n. 1, p. 5-15, jan./fev./mar/abr. 1996.

${ }^{47}$ MÉSZÁROS, Istvan. A educação para além do capital. Campinas : Boitempo, 2005.

48 KUENZER, Acácia. Educação profissional: categorias para uma nova pedagogia do trabalho. Boletim Técnico do Senac, Rio de Janeiro, v. 25, n. 2 p. 19-29, maio/ago, 1999.

49 LEHER, Roberto. Educação no Governo Lula da Silva: reformas sem projeto. Revista ADUSP, Associação dos Docentes da USP, n. 34, maio, 2005.

${ }^{50}$ FRIGOTTO, Gaudêncio; CIAVATTA, Maria; RAMOS, Marise. A política de educação profissional no Governo Lula: um percurso histórico controvertido. Educação \& Sociedade, Campinas, v. 26, n. 92, p. 1087-1113, 2005

51 BRASIL. Leis, Decretos. Decreto n. 5.154, de 23 de julho de 2004. In: BRASIL. Ministério da Educação. Secretaria de Educação Profissional e Tecnológica. Educação profissional e tecnológica : legislação básica. 6. ed. 2005. p. 5-7. Disponível:https://www.planalto.gov.br//ccivil_03/_Ato2004-2006/2004/ Decreto/D5154.htm.Regulamenta o paragráfo $2^{\circ}$ do art. 36 e os art. 39 a 41 da Lei n. 9.394, de 20 de dezembro de 1996, que estabelece as diretrizes e bases da educação nacional, e dá outras providências.

52 Os jovens passam por um processo de qualificação, durante cinco meses, de segunda a sexta-feira, com carga de 500 horas, distribuídas em duas etapas. $\mathrm{Na}$ primeira etapa, reservam-se 200 horas para ações da qualificação básica, que inclui aulas de informática, valores humanos, saúde, promoção da igualdade racial e equidade de gênero, estímulo à escolaridade (competências em Língua Portuguesa e Matemática), ética e cidadania e educação ambiental. A outra etapa consiste em uma capacitação profissional, de também 200 horas, com oficinas-escolas, de acordo com a demanda de emprego da região, além de 100 horas de trabalho voluntário em projetos comunitários (Serviço Social Voluntário) (distribuídas em 20 horas mensais). Durante esse processo, os jovens participantes recebem uma bolsa cidadania de $\mathrm{R} \$ 120,00$ para possibilitar sua permanência no curso.

${ }^{53}$ Não há uma compreensão única por parte das entidades executoras sobre o conteúdo da qualificação básica. No caso das aulas de Matemática, por exemplo, para a entidade $\mathrm{X}$, tratam-se de aula de raciocínio lógico; para Z, trata-se de matemática instrumental, voltada para uso no mercado de trabalho e dia-a-dia dos jovens, ao passo que Y não desenvolve aula de Matemática.

${ }^{54}$ Produzido pelo Consórcio Social da Juventude do Paraná, são três os Cadernos Pedagógicos: o Básico, no qual são trabalhadas as questões referentes à cidadania (ética, mercado de trabalho, leis trabalhistas, meio ambiente e qualidade de vida); o de Inclusão digital e o de Estímulo ao aumento da escolaridade (Português e Matemática).

55 MARX, Karl. (1978), op. cit.

56 MANACORDA, Mario Alighiero. O princípio educativo em Gramsci. 
Porto Alegre : Artes Médicas, 1990.

57 SMITH, Adam. Riqueza das nações: investigação sobre sua natureza e suas causas. 2. ed. Trad. de João Baraúna. São Paulo : Nova Cultural, 1985. v. 2.

${ }^{58}$ Id. Ibid., p. 217.

${ }^{59}$ GRAMSCI, Antonio. (1995), op. cit.

${ }^{60}$ GOHN, Maria da Gloria. Educação, trabalho e lutas sociais. In: GENTILI, Pablo.; FRIGOTTO, Gaudêncio. A cidadania negada: políticas de exclusão na educação e no trabalho. $3^{\text {a }}$ ed. Rio de Janeiro : Cortez , 2002. p. 95.

${ }^{61}$ GRAMSCI, Antonio (1995), op. cit.

${ }^{62}$ DELUIZ, Neise. A globalização econômica e os desafios à formação profissional. Boletim Técnico do Senac, Rio de Janeiro, v.30, n. 3, set./dez., 2004.

${ }^{63}$ KUENZER, Acácia. op. cit.

${ }^{64}$ MANACORDA, Mario. (1990), op. cit., p. 184.

${ }^{65}$ GOHN, Maria da Gloria. G. (2002), op. cit.

${ }^{66}$ MÉSZÁROS, Istvan. (2005), op. cit.

${ }^{67}$ OLIVEIRA, Dalila. A; DUARTE (2005), op. cit.

${ }^{68}$ MONTAÑO, Carlos. (2007), op. cit., p. 273.

(69) Id ibid.

${ }^{70}$ MÉSZÁROS, Istvan. Para além do capital. Campinas : Boitempo, 2002.

71 WOOD, E. M. Democracia contra capitalismo: a renovação do materialismo histórico. Campinas : Boitempo, 2003.

72 MONTAÑO, Carlos. (2007), op. cit.

73 Id. Ibid. , p. 262-263.

${ }^{74}$ WOOD, E. M. (2002), op. cit.

${ }^{75}$ GRAMSCI, A. (1995), op. cit.

${ }^{76}$ Encontramos, entre os educadores entrevistados, membros do sindicato dos professores, participantes de movimentos sociais, mestres e pesquisadores da área de trabalho e educação e de políticas públicas de juventude, conscientes da problemática aqui exposta e orientando suas ações para uma outra direção, isto é, para a formação do sujeito político.

${ }^{77}$ FRIGOTTO, Gaudêncio. (1998), op. cit., p. 48.

${ }^{78}$ DELUIZ, Neise. As organizações da sociedade civil e suas propostas e práticas de educação profissional: um estudo das ONGs do Rio de Janeiro. Rio de Janeiro, 2006. Relatório Final de Pesquisa/ CNPq.

79 O conceito de capital social foi desenvolvido por Robert Putnam (The prosperous community: social capital and public Life. The American Prospect., n. ${ }^{\circ}$ 13, mar., 1993. Apud SOUZA, Jorge Renato. Desenvolvimento regional endógeno, capital social e cooperação. Disponível em: < http://nutep. ea.ufrgs.br/pesquisas/Desenvolvreg.html> . Acesso em: 09.02.2008), como o conjunto das características da organização social, que englobam as redes de relações, normas de comportamento, valores, confiança, obrigações e canais de informação - que, quando existente em uma região, torna possível a tomada de ações colaborativas que resultem no benefício de toda comunidade. $\mathrm{O}$ capital social pode ser considerado a base de uma das principais estratégias de desenvolvimento econômico nas próximas décadas: a cooperação. Tanto a idéia de capital social quanto a de cooperação têm sido destacadas nos últimos anos por organismos internacionais, em revistas especializadas e em diversos estudos e políticas de desenvolvimento.

\section{ABSTRACT}

Carlos Soares Barbosa; Neise Deluiz. Vocational qualification of young and adult workers: discussing the National Program to Stimulate the First Job.

This article analyzes vocational qualification actions geared to young people from low-income sectors covered by the National Program to Stimulate the First Job (PNPE) in Rio de Janeiro. Qualitative research results indicate that these actions refer young people to precarious jobs, making them responsible for non-insertion into the formal labor market. Because the Program does not foster the development of political actors and their participation in the public sphere, it is limited to secondary benefits, such as the promotion of sociability and self-esteem. Thus, the PNPE program plays the role reserved to focused policies geared to alleviate poverty and control social struggles.

Keywords: Vocational Training; Public Policies; NonGovernment Organizations; Youth; National Program to Stimulate the First Job.

\section{RESUMEN}

Carlos Soares Barbosa; Neise Deluiz. Calificación profesional de jóvenes y adultos trabajadores: el Programa Nacional de Estímulo al Primer Empleo en discusión.

El articulo analiza las acciones de calificación profesional dirigidas hacia los jóvenes pertenecientes a los sectores populares del Programa Nacional de Estímulo alPrimer Empleo (PNPE), en Río de Janeiro. Los resultados de una investigación cualitativa indican que dichas acciones conducen a los jóvenes a trabajos precarios, baciéndolos responsables por la no inserción en el mercado de trabajo formal. Al no propiciar la formación de sujetos políticos ni su participación en la esfera pública, se limitan a facilitar beneficios secundarios, como la sociabilidad y la autoestima, cumpliendo entonces el PNPE la función reservada a las politicas centradas en el alivio de la pobreza $y$ en la contención de la lucha social.

Palabras clave: Educación Profesional; Politicas Públicas; Organizaciones No Gubernamentales; Juventud; Programa Nacional de Estímulo al Primer Empleo. 